\title{
EDITORIAL
}

\section{Los metabolitos secundarios de las plantas y potencial uso en el manejo de plagas agrícolas en agroecosistemas desérticos}

\author{
Secondary plant metabolites and their potential use in the management \\ of agricultural pests in desert Agroecosystems
}

\author{
Tommy Christian Rioja Soto \\ Facultad de Recursos Naturales \\ Renovables \\ Universidad Arturo Prat \\ Iquique, Chile
}

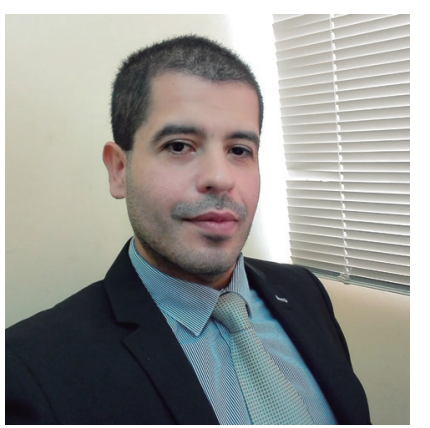

Tommy Christian Rioja Soto

Faculty of Renewable Natural

Resources

Arturo Prat University

Iquique, Chile.
En su evolución las plantas han desarrollado diversos mecanismos de defensas para afrontar los efectos de estreses, tanto bióticos como abióticos. Su plasticidad fenotípica y la presión de selección han provocado una constante lucha química hacia herbívoros, microorganismos, nematodos, y ácaros; asimismo, las defensas de las plantas se han adecuado a los continuos estreses abióticos como sequía, salinidad, radiación ultravioleta, temperatura, inundaciones, y concentraciones de $\mathrm{CO}_{2}$. Por lo tanto, la evolución y micro-evoluciones de las plantas dentro del contexto defensivo, se encuentran en estrecha relación con el medio ambiente que las rodea.

Aunque muchos no acepten el concepto, las plantas "hablan" e "informan" al medio ambiente de su estado clínico, indicando de manera específica si están siendo atacadas por insectos, ácaros, nematodos, microorganismos, o afectadas por algún estrés abiótico. Al respecto, dicho "lenguaje químico" ocurre a través de la producción constitutiva de metabolitos secundarios, y la posterior emisión de los Compuestos Volátiles Orgánicos Biogénicos (CVOB) hacia la atmosfera. Después de ocurrida la herbivoría, y la detección a nivel de membrana plasmática de moléculas presentes en la saliva de insectos y ácaros (elicitores y efectores), se activan diversos mecanismos defensivos específicos a nivel fisiológico y genético en las plantas, con influjos de $\mathrm{Ca}^{+}$, depolarización de la membrana
In their evolution, plants have developed various defense mechanisms to cope with the effects of stress, both biotic and abiotic. Its phenotypic plasticity and selection pressure have caused a constant chemical fight against herbivores, microorganisms, nematodes, and mites; ikewise, plant defenses have been adapted to continuous abiotic stresses such as drought, salinity, ultraviolet radiation, temperature, floods, and $\mathrm{CO}_{2}$ concentrations. Therefore, the evolution and micro-evolutions of plants within the defensive context are closely related to the environment that surrounds them.

Although many do not accept the concept, plants "speak" and "inform" the environment of their clinical state, specifically indicating if they are being attacked by insects, mites, nematodes, microorganisms, or affected by some abiotic stress. In this regard, said, "chemical language" occurs through the constitutive production of secondary metabolites, and the subsequent emission of Biogenic Volatile Organic Compounds (BVOCs) into the atmosphere. After the herbivory has occurred, and the detection at the plasma membrane level of molecules present in the saliva of insects and mites (elicitors and effectors), various specific defensive mechanisms are activated at the physiological and genetic level in plants, with influx of $\mathrm{Ca}^{+}$, depolarization of the plasma membrane, oxidations and production of reactive oxygen species, changes 
plasmática, oxidaciones y producción de especies de oxígeno reactivos, cambios en los niveles del ácido jasmónico (AJ), ácido salicílico (AS) y etileno (ET), principalmente. Así, los niveles basales de los metabolitos secundarios son incrementados, y por consiguiente, sus emisiones cambian cualitativa y cuantitativamente. Dichas emisiones pasan a denominarse Compuestos Volátiles Orgánicos Inducidos por Herbívoros (CVOIH), los cuales atraen enemigos naturales de las plagas, como depredadores y parasitoides, originándose así, interacciones tri-tróficas en los agroecosistemas. Con respecto a esto, en Norte América y Europa se utilizan dispensadores de liberación lenta en base a alomonas y sinomonas, como metil salicitato (MeSA), metil jasmonato (MeJA) y terpenoides, para repeler plagas y atraer enemigos naturales en cultivos orgánicos y de producción limpia. Por lo tanto, el metabolismo secundario de las plantas presenta características ideales para la generación de nuevas técnicas y productos alternativos a pesticidas de amplio espectro y tóxicos para trabajadores, consumidores y el medio ambiente.

Generalmente, las plantas que crecen en ambientes desérticos desarrollan defensas adicionales para atenuar los efectos de altas temperaturas, rayos ultravioleta, sequía y salinidad. En relación a esto, existe escasa información relacionada a dichos fenómenos, los cuales tienen una potencialidad inconmensurable para ser investigada dentro del contexto de la innovación y generación de nuevos productos biotecnológicos de origen natural, provenientes de agroecosistemas del norte de Chile.

Los recursos genéticos vegetales y animales, microfauna del suelo, ecología química y ecotipos presentes en los valles y el altiplano de la Región de Arica y Parinacota, han sido escasamente investigados; lo mismo ha ocurrido en los valles y oasis de la Región de Tarapacá. Esto representa un gran desafío y oportunidad para el estudio de los agroecosistemas desérticos en dichas regiones, los cuales pueden ser catalogados como verdaderos laboratorios con gran potencial para el desarrollo de nuevas estrategias y tecnologías sostenibles, para el manejo de plagas agrícolas en zonas semi-desérticas y desérticas de Chile y el mundo.

Por otro lado, el cambio climático y el constante aumento de las concentraciones de $\mathrm{CO}_{2}$ a nivel mundial, que actualmente sobrepasan las 415 partes por millón (ppm), afectarán considerablemente las producciones agrícolas, indispensables para la in the levels of jasmonic acid (JA), salicylic acid (SA) and ethylene (ET), mainly. Thus, the basal levels of secondary metabolites are increased, and consequently, their emissions change qualitatively and quantitatively. These emissions are renamed Herbivore-Induced Plant Volatiles (HIPVs), which attract natural enemies of pests, such as predators and parasitoids, thus causing tri-trophic interactions in agroecosystems. In this regard, in North America and Europe, slow-release dispensers based on allomones and synomones, such as methyl salicylate (MeSA), methyl jasmonate (MeJA) and terpenoids, are used to repel pests and attract natural enemies in organic and clean productions. Therefore, the secondary metabolism of plants presents ideal characteristics for the generation of new techniques and alternative products to broad-spectrum and toxic pesticides for workers, consumers, and the environment.

Generally, plants that grow in desert environments develop additional defenses to mitigate the effects of high temperatures, ultraviolet rays, drought, and salinity. In this regard, there is little information related to these phenomena, which have immeasurable potential to be investigated within the context of innovation and generation of new biotechnology products of natural origin, originating from agroecosystems in northern Chile.

The plant and animal genetic resources, soil micro-fauna, chemical ecology, and ecotypes present in the valleys and the highlands of the Arica and Parinacota Region have been scarcely investigated; the same has happened in the valleys and oases of the Tarapacá Region. These resources represent a great challenge and opportunity for the study of desert agroecosystems in these regions, which can be classified as actual laboratories with great potential for the development of new strategies and sustainable technologies for the management of agricultural pests in semi-desert areas, and desert of Chile and the world.

Furthermore, climate change and the constant increase in $\mathrm{CO}_{2}$ concentrations worldwide, which currently exceed 415 parts-per million (ppm), will considerably affect agricultural production, essential for human consumption. In this regard, increases in $\mathrm{CO}_{2}$, drought and high temperatures will cause the resetting of trophic interactions between species, the silencing of genes associated with plant defenses (e.g., high concentrations of $\mathrm{CO}_{2}$ repress the signaling of the phytohormone JA defense), 
alimentación humana. Al respecto, los incrementos en $\mathrm{CO}_{2}$, la sequía y las altas temperaturas provocarán: el reseteo de las interacciones tróficas entre especies, el silenciamiento de los genes asociados a las defensas de las plantas (i.e. altas concentraciones de $\mathrm{CO}_{2}$ reprimen la señalización de la fitohormona de defensa $\mathrm{AJ}$ ), disminución de la tolerancia y/o resistencia de las plantas (i.e. plantas con estrés hídrico acumulan AJ, afectando la expresión de los genes de defensa asociados al AS, incrementando la susceptibilidad hacia insectos hemípteros y ácaros fitófagos), la extinción de algunas especies vegetales, incrementos en el fitness, reproducción y población de artrópodos plaga por mayor disponibilidad de biomasa vegetal (i.e. plantas con metabolismo $\mathrm{C}_{3}$ incrementan su biomasa en ambientes ricos en $\mathrm{CO}_{2}$ ), y cambios en la producción y emisión de los CVO y CVOIH hacia el medio ambiente.

Por lo tanto, las condiciones extremas del norte de Chile, son ideales para estudiar los potenciales escenarios que se visualizan en el ámbito fitosanitario agrícola mundial, cuyo objetivo principal deberá ser el diseño de nuevas estrategias, obtención de nuevas variedades, desarrollo de biopesticidas en base a extractos vegetales, y dispositivos con compuestos sintéticos que simulen las defensas de las plantas, para ser incorporados en futuros programas de manejo holístico y sostenible de plagas agrícolas, en agroecosistemas áridos alrededor del mundo. decreased tolerance and resistance of plants (e.g., plants with water stress accumulate JA, affecting the expression of defense genes associated with SA, increasing susceptibility to Hemiptera insects and phytophagous mites), extinction of some plant species, increases in fitness, reproduction and population of arthropod pests due to higher availability of plant biomass (i.g., plants with C3 metabolism increase their biomass in environments rich in $\mathrm{CO}_{2}$ ), and changes in the production and emission of BVOCs and HIPVs towards the environment.

Therefore, the extreme conditions in northern Chile are ideal for studying the potential scenarios that are visualized in the world agricultural phytosanitary field, whose main objective should be the design of new strategies, obtaining new varieties, development of biopesticides based on plant extracts, and devices with synthetic compounds that simulate the defenses of plants, to be incorporated in future programs of holistic and sustainable management of agricultural pests, in arid agroecosystems around the world. 